Review Article

\title{
Agriculture Crop Residues Disinfection Methods and Their Effects on Mushroom Growth
}

\author{
N A NANJE GOWDA ${ }^{1, *}$ and DRONACHARI MANVI ${ }^{2}$ \\ ${ }^{1}$ Department of Food Technology, FLAHS, Ramaiah University of Applied Sciences, Bengaluru, \\ Karnataka, India \\ ${ }^{2}$ Departmet of Agricultural Engineering, University of Agricultural Sciences, GKVK, Bengaluru, \\ Karnataka, India
}

(Received on 17 June 2018; Revised on 19 July 2019; Accepted on 14 August 2019)

\begin{abstract}
Agriculture crop residues have been effectively utilized as substrates for mushroom cultivation from ancient times. For cultivation of edible mushrooms from these substrates requires various pre-treatments in order to promote the growth of mushroom mycelium by excluding other competitor microorganism. The various pre-treatments such as hot water boiling, pasteurization by hot water and chemical, sterilization, steam treatments etc. are employed cross the world. However, pretreatment specifically the sterilisation is not an ideal disinfection method for mushroom substrate, since it kills both beneficial and harmful organisms in the substrate. In this context, the pasteurization will not only arrests the growth of competitor fungi such as Coprinus cinereus, Trichoderma harzianum and Coprinus comatus but also breakdown the lignin and cellulose compounds in substrate for enzymatic degradation and make the substrate more favourable for mycelial growth. Studies have proven that pasteurisation of the substrate seems to be an ideal disinfection method which permits regrowth of beneficial organisms during the cooling period. This paper presents an outline on the utilisation of agro residues as substrate in mushroom cultivation; various chemical and non-chemical sterilization and pasteurisation methods with their benefits and drawbacks in mushroom cultivation. The information generated in this paper shows the lack of knowledge on pasteurization equipment which offers a great potential to develop simple and low cost pasteurization equipments for a successful long term mushroom cultivation business. More policies are required to promote the mushroom cultivation which is an eco-friendly disposal of agriculture crop wastes. This would inturn positively influence the overall human nutrition, and improve the economic standards of families.
\end{abstract}

Keywords: Agro Residues; Mushroom; Substrate; Disinfection; Pre-Treatment; Pasteurization

\section{Introduction}

The agricultural residues are of two types: crop residues in the field and agro-industrial residues from processing industries. Most crop residues are plant materials like root, stem, stalk, straw, leaves, and branches which are obtained at the field. Agroindustrial residues are the by-products obtained during post-harvest processing of crops yielding residues like shell, husk, bran, cob, straw, and other fibrous materials (Satyendra et al., 2013). Overall, India produces annually about 500-550 MT of agricultural crop residues, of which nearly 85-100 MT of crop residues are burnt on the field itself (MNRE, 2009; Devi et al., 2017). These residues are widely used as packaging material, animal feed, biomass, thatching for rural homes, biomass production, domestic/ industrial fuel, composting for mushroom cultivation, and in situ incorporation and green manure (Satyendra et al., 2013).

The total un-utilized residue available in India is shown in Fig. 1. The annual estimated surplus residues availability for bio-energy generation was $234 \mathrm{MT}$, of which 92.8MT residues are burnt in the field with intent of making the field free from straw and stubble after the harvest of crop (Pathak et al., 2010; Hiloidhari et al., 2014). However, in case of rice and

*Author for Correspondence: E-mail: nanjegowdana@gmail.com 
wheat fields, if combine harvesters are used for harvesting almost all the residues are left out in the field, resulting in in-situ burning. According to Thakur (2003), for every 4 tonnes of wheat and rice grain harvested, about 6 tonnes of straw is produced. In this context, during 2011 India's production of rice was $155.7 \mathrm{MT}$ and wheat was $86.87 \mathrm{MT}$ which had produced nearly 233.55 of rice straw and 130.3 MT of wheat straw (Anon, 2013).

The main reason which makes farmers to burn the residue on farm is to clean the field for sowing the next crop. In addition, decreased labour availability, increased labour wages, declining number of livestock, rapid removal of residue from the field, a fast way of controlling weeds, insects and diseases, pest and pasture management, less economically viable alternate use of residues and increased mechanisation has resulted in more usage of combine harvester leaving $>80 \%$ of residue in the field. Hence, it is difficult for farmers to utilize or dispose these residues within a short period of time. In situ incorporation of residues takes longer duration for decomposition and hence burning facilitates farmers for early land preparation for sowing next crop. And also these residues are of high moisture content, low bulk density, irregular shape and size, and high carbon and nitrogen content, it is difficult to handle, transport, store, dispose and utilize residues appropriately (Sokhansanj et al., 2005).

\section{Utilization of Agro Residues for Mushroom Cultivation}

The crop residues management is vital for long-term sustainability of Indian agriculture. Hence, burning of residues must be avoided and should be used positively so as to improve the economic returns of farmers and reduce the environmental impacts. A potential and promising agro-residues management which can attract the farmer would be mushroom cultivation. This technique has various benefits such as: the reduction in environmental pollution; generation of employment, particularly for rural women and youth; mode of short return agricultural business offering immediate benefit to the community; enrichment the human diet and fitness with high nutrition and nutraceutical compounds; improvement of economic standards of family. Mushroom production has a great potential for exploitation of forest and agricultural residues (Nigam et al., 2009).

Mushrooms are cultivated from wide varieties of lignocellulosic residues. Paddy straw, wheat straw, maize straw, cotton waste, and sugar cane waste are the most widely used substrates. However, cereals straw has gained more importance in mushroom cultivation due to its high nutrient composition. These agricultural residues can either be used alone or combination of several residues in order to enrich the nutrients required for mushroom growth. There are several studies which suggest that the supplementation of substrates would increase yield, as compared to the use of single substrate. This is because these supplements favour quick mycelia impregnation of substrate as well as an earlier primordial initiation with good number of fruiting bodies (Pani et al., 1997). Mushroom can be grown on almost all types of organic wastes available. Some of the successful mushroom cultivations from several residues are presented in Table 1.

\section{Bioconversion of Agro Residues into Mushroom}

Mushrooms are macro fungus with distinctive fruiting body that can be either epigeous or hypogeous and usually grows in decaying organic matter. Generally mushrooms have a two-phase life cycle, the mycelium (vegetative or colonization phase) and the fruiting body (reproductive phase that bear the spores). Mycelia secrete enzymes during their vegetative growth phase, which breakdown compounds such as cellulose and lignin present in the substrate (Wood and Smith, 1987). The carbon and nitrogen content in the substrate also plays a vital role in mycelium running and mushroom growth. Since basidiomycetes use carbon sources, the fungi during vegetative growth produce a wide range of enzymes to degrade the lignocellulosic substrates. All plant materials are mainly composed of low molecular weight substances such as organic, inorganic matter and macromolecular substances such as lignin, cellulose, hemi-cellulose, and to a lesser extent pectin, starch and other polysaccharides (Thomsen, 2005). The seligno cellulosic materials are converted into substrate by mushroom fungi through enzymatic degradation and there conversion productivity is expressed as its biological efficiency (Chang et al., 1981). The mycelium growth, mushroom quality and crop yield are mainly affected by nutrient composition (Philippoussis et al., 2003). 
Table 1: Mushroom grown on various agricultural residues in India

\begin{tabular}{lll}
\hline Mushroom variety & Residues & Reference \\
\hline Pleurotus species & $\begin{array}{l}\text { Banana leaves; cinnamon leaves; coconut fiber pith and coir; coconut husks; coffee } \\
\text { pulp; corn fiber, cottonseed hulls; groundnut shells; maize straw; soybean stems }\end{array}$ & Kwon and Kim, 2004 \\
& $\begin{array}{l}\text { and husk; sunflower stipes, wheat straw; paddy straw; bajara leaves; jowar leaves; } \\
\text { sugar cane bagasse; saw dust etc. }\end{array}$ & Kwon and Kim, 2004 \\
Volvariella species & $\begin{array}{l}\text { Barley straw; coconut coir, fibre \& husks; cotton wastes; wheat straw; paddy } \\
\text { straw; oil palm fibre; sawdust; banana leaves; rice husk etc. }\end{array}$ & Kwon and Kim, 2004 \\
\hline Calocybeindica & $\begin{array}{l}\text { Rice straw; wheat bran; sawdust; coir pith; paddy straw; maize stalk; sunflower } \\
\text { stalk; sesame stalk; sugarcane bagasse; cotton waste etc. }\end{array}$ & \\
\hline
\end{tabular}

For an instance, (Zadrazil 1975a) have shown that cellulose, hemicellulose and lignin are the major constituents of plant waste and have direct impacts on the growth and development of mushroom fungi. Singh et al. (1989) observed that $75 \%$ of cellulose, hemicellulose and lignin are degraded during the growth period. The variation in the carbon and nitrogen ratio is also crucial in substrate degradation and mycelium growth. At optimum $\mathrm{C}: \mathrm{N}$ ratio for best fungus growth in case of paddy straw is $82.5: 1$. For instance, (Narain et al., 2008) reported that mushroom mycelia growth and development is dependent on the lignocellulosic materials especially the C:N ratio. Quimio (1981) recommended an optimum C:N ratio of 90:1 for better growth of Pleurotus spp. mushrooms. Apart from nutrient composition, mycelial growth and fruiting of fungi are also regulated by temperature, gaseous composition, water activity, light and purity of substrate that is free from competitor microorganisms. It is said that for successful mushroom cultivation, disinfection of the substrate prior to inoculation with spawn is a crucial task (Chang and Hayes, 2013).

\section{Agro-residues Disinfection}

There are several thousands of mushroom varieties available across the world and about 2,500 varieties of mushrooms are known to be edible, out of which only 280 species are cultivated in India (Christensen and Martin, 1969). The basic procedure involved in almost all the varieties of mushrooms remains same till substrate preparation, later few varieties needs additional casing material after spawn running period during mycelium growth. The most important step in the mushroom substrate preparation is its disinfection, which has some relation to the pasteurization or sterilization used for milk and other liquids. Thus substrate preparation by disinfection of agro residues is difficult and most expensive operation since it requires fuel-consumption for boiling or steaming. Nevertheless this is so important for obtaining high yield, it is a critical, tricky and labour-intensive.

There are several reasons which make the disinfection process a critical step in mushroom growth. Another study reported by Chang (2008) showed that the substrate pre-treatment for cultivating edible mushrooms (Pleurotusostreatus), would promote the growth of mushroom mycelium by eliminating other competitor microorganisms. Hydrothermal treatments of agro residues also have various effects including extractive removal, hydrolysis of hemicellulose to produce sugars and also alter the cellulose and lignin properties (Lamptey et al., 1985). It is said that in the cell wall, both cellulose and hemicellulose are encrusted within the lignin, thus lignin acts as a barrier against the availability of carbohydrates. Hence, hydrothermal treatment is essential to obtain a good degree of fermentable sugars for mushroom growth by breaking this barrier. Since, pre-treatment alters the cellular structure inside the agro-industrial residues and makes substrate more accessible to enzymes that converts the carbohydrate polymers into fermentable sugars and to cellulase producing microorganisms (Mosier et al., 2005). A study outcome by Diana et al. (2006) proved that disinfection of substrate (corn cob) is absolutely necessary which permits mycelia to grow better and faster, as the yield from substrate without disinfection was less than half of the yield from disinfected substrate. A similar case was reported by Muhammad et al., 2007, which showed the importance of cotton waste disinfection on Pleurotus yield. The pasteurization of substrate at $65^{\circ} \mathrm{C}$ for $6-8$ hour was done to soften the texture of substrate and kill 
mesophilic microorganism, but mould spores are stable at $65^{\circ} \mathrm{C}$ which can be killed at temperature above $80^{\circ} \mathrm{C}$ (Choi, 2004). Most essentially, disinfection of substrate is done to kill the competitor moulds such as Trichoderma spp., Coprinus spp., Penicillium and Aspergillus appear during colonisation and beginning of fruiting. These species cause green mould which is one of the most common and destructive diseases in mushroom cultivation.

The first person who identified the presence of Trichoderma in mushroom compost was Kligman (1950) and T. harzianum was recognised to induce significant quantitative and qualitative losses in the yield (Morris et al., 2000). The Coprinus spp. was found to cause inky caps during spawn run on the mushroom beds (Sharma et al., 2007). These two competitor moulds are common and causes green mould disease which hampers the growth mycelium (Lopez, 1996). According to Balasubramanya \& Kathe (1996), the fungi Penicillium sp. and Trichoderma sp., are the competitors with Pleurotus sp. after pasteurization with hot water at $80^{\circ} \mathrm{C}$ for 2 hour, this was probably due to the partial breakdown of cellulose and hemicellulose, making them available to competitors. These competitor moulds will grow because of insufficient substrate pasteurization or excessive use of nitrogen will inhibits the synthesis of lignin degrading enzyme (Bisaria et al., 1997). Another reason behind heat treatment above $60^{\circ} \mathrm{C}$ will immediately melts the natural waxy coating on straw materials. Hence, this melting process permits the water to easily penetrate and wet the dry substrate material which is difficult to achieve using cold water. Simultaneously, heat inside the straw kills the pathogens present and will not give another chance for growth of new microorganisms (Kurtzman, 2010).

Only one review was written by Kurtzman (2010) on pasteurization with simple methods and good management to minimize the amount of fuel and reduce pests and disease were discussed and effect of pasteurization and sterilization of substrate on Oyster mushroom yield were also shown in the literature. However, till date there is no review available on substrate disinfection methods, so the disinfection methods followed vary with respect to type of residues to be disinfected and energy sources available as per several investigators. Thus the disinfection methods currently followed are those developed earlier. In this review, the various disinfection methods (chemical and non-chemical) developed and adopted from two to three decades to treat different agro-residues, superiority of these methods and their inference are briefly discussed.

\section{Conventional Methods of Substrate Disinfection}

Substrate disinfection before spawning is important operation to kill or reduce pests and microorganisms. Disinfection can be done in two methods: sterilization and pasteurization. Sterilization will kill both beneficial and harmful microorganisms, while pasteurization will only reduce the number of microorganisms. The most common method followed is injected steam into chambers, where the substrate is packaged. The pasteurization time varies as a function of the temperature (Abe et al., 1992; Mansur et al., 1992). However, the pasteurization time-temperature will depend on type of pathogen present inside substrate. Hence, selection of right pasteurization time and temperature is always a challenging task to retain the beneficial organism in disinfected substrate. The methodology for substrate preparation is reported by several studies which include composting the agricultural residues, followed by disinfection of substrate which can be done in several ways (Balasubramanya and Kathe, 1996). From many decades it has been routine to "pasteurize", "decontaminate", "disinfection", "peak heat", "pretreatment", "cook out", or "Phase-II" of mushroom substrate. All these terms refer to blowing steam or pour hot water into substrate at $60^{\circ} \mathrm{C}$ for few hours to achieve any one of these terms (Denham, 1975).

Few methods for substrate pasteurization and sterilization such as (1) autoclaving (axenic), (2) axenic and inoculation with thermophilic microorganisms, (3) steam treatment between 80 to $100^{\circ} \mathrm{C}$ for several hours, (4) NA746. DASI system: Pasteurization at $72^{\circ} \mathrm{C}$ for $4-5$ days, and (5) tunnel pasteurization by steam treatment at $60^{\circ} \mathrm{C}$ for several days were proposed by Laborde and Delmas (1974) and Valencia and Lopez (2005). According to Sinden and Hauser, (1953) the best way to eliminate the unwanted microorganisms is to prepare substrate by short method (pasteurize). However, still there is little confusion among the several mushroom growers weather to pasteurize or sterilize the straw for better growth and yield of mushrooms. Treschow, 1944, was 
one who confused the meaning of "serialization" by combining the process temperatures of both pasteurization and sterilization together. Though he treated the substrate for Agaricus at 60, 80, 100 and $120^{\circ} \mathrm{C}$ all for $1 \mathrm{~h}$, the process was termed as sterilization process for all temperature range used, rather convincing it as pasteurization based on results obtained.

\section{Chemical Sterilization of Substrate}

Mushroom growers prefer chemical sterilization to decontaminate the substrate because autoclaving, hot water, and steam pasteurization are expensive due to the high cost of the equipment. Chemical sterilization can be done easily for large amount of straw with less expensive, since it does not require additional machinery. Several chemicals are used for sterilization of straw, however only few chemicals have shown better results, which includes formaldehyde and hydrogen peroxide are most commonly used. Indrea and Apahidean (1995) has suggested chemical disinfection can also be done with diluted solutions of fungicide. The sterilization of substrate using different chemicals is compiled in Table 2. The alkaline immersion technique (AIT) shown in Table 2 is a simple chemical disinfection method, which is inexpensive and non-thermal technique performed by soaking substrate for 12 to $48 \mathrm{~h}$ in limed water. Contreras et al. (2004) suggested the methodology of AIT, later this was followed by several workers. But the drawbacks of this method are: chances of bacterial contamination and survival of fly eggs, presoaking of straw overnight is necessary, longer time duration, and lesser mushroom yields and B.E. (De Leon-Monzon et al., 2004; Hernandez and Sanchez, 2013).

\section{Non Chemical Sterilization of Substrate}

The sterilization of substrate can be achieved either by hot water, steam or chemical method. Generally boiling water and hot steam is useful for sterilization of substrate in small scales, while for large scale disinfection it is difficult, hence growers prefer chemicals such as Bavistin, Formaldehyde, Carbendazim, etc. Chemical sterilization is easy operation and cost effective method for disinfecting large volume of substrate. The first attempt for Pleurotus cultivation in sterilized substrate was reported by Falck (1917), during early decades of 20th century. Oei (1996) recommended the sterilization of substrate as appropriate method for mushroom cultivation. Zanetti and Ranal (1996) showed the substrate sterilization can also be done using autoclaves. Kwon and Kim (2004) sterilized substrate bags in two ways. Firstly, in normal pressure sterilizer at temperature of either 90 to $95^{\circ} \mathrm{C}$ for 5 to $8 \mathrm{~h}$ or $100^{\circ} \mathrm{C}$ for $1 \mathrm{~h}$ is maintained. Secondly, in high pressure autoclave temperature of $121^{\circ} \mathrm{C}$ for 60 to 90 minutes is maintained under pressure between 15 to 20 psi. Similarly, Villaceran et al. 2006 sterilized the polypropylene bags filled with $1000 \mathrm{~g}$ of rice straw for one hour at $121^{\circ} \mathrm{C}$ at $15 \mathrm{psi}$ pressure. The different hot and steam sterilization techniques employed within the last few decades were compiled and shown in Table 3.

Sterilization of substrate was found to have more drawbacks than pasteurized substrate, some of the drawbacks reported by few researchers includes. Quimio et al. (1990) observed the substrate sterilisation is not an ideal disinfection solution, since it kills both beneficial and harmful organisms in the substrate. Maintenance of the substrate at $70^{\circ} \mathrm{C}$ for $24 \mathrm{~h}$ in hot water was recommended by Miroslawa (1991). The pasteurization will selectively kills only temperature sensitive micro-organisms, while permitting remaining population to grow with less competition against mycelia growth and also provide an ample opportunity for the mushroom mycelium to colonize (Stamets, 1993). Similarly, Diana et al. (2006) have suggested before spawning, the disinfection of substrate should only destroy only the competitive fungi, but not the beneficial microorganisms. Since beneficial microorganisms do not compete against mycelia growth but they interrupt the development of competitive microorganisms (Apahidean, 2006). This suggests that it is better to pasteurize the substrate rather than sterilization. In addition, sterilisation of substrates is not an easy job for mushroom growers, since determining the right sterilisation time and temperature depend on type of pathogens present in the straw material (Kwon and Kim, 2004). The oyster mushrooms substrate does not requires sterilization, simple pasteurization would be sufficient to reduce the pathogenic damage (bacteria, mould and insect pests) caused on mycelia development and yield (Sanchez, 2010). 
Table 2: Chemical sterilization of various substrates used in mushroom cultivation

\begin{tabular}{lll}
\hline Chemical & Inference & Reference \\
\hline $100 \mathrm{~kg}$ of substrate treated in $150 \mathrm{ml}$ of & Effective in controlling yellow molds (M. Lutea and & Vijay and Sharma, 1996 \\
Formalin $+5 \mathrm{~g}$ of Bavistin solution & S. chrysospermum) in Agaricusbisporus &
\end{tabular}

$1 \mathrm{~m}^{3}$ of cotton waste treated in formalin $(0.5 l)$ in water $(10 l)$

Paddy straw soaked in water for $12 \mathrm{~h}$ and treated with

1. Formaldehyde (500ppm) + Bavistin (75ppm)

2. Hydrogen peroxide solution at $1.5 \%, 3.0 \%$, $6.0 \%$ and $8.0 \%(\mathrm{v} / \mathrm{v})$

3. Bleaching powder solution ( $33 \%$ chlorine) at $2 \%, 4 \%, 6 \%, 8 \%$, and $10 \%(\mathrm{w} / \mathrm{v})$

Wheat straw sterilized with Carbendazim $(75 \mathrm{ppm})+$ Formalin $(500 \mathrm{ppm})$ for $18 \mathrm{~h}$

Paddy straw sterilized with Carbendazim $(75 \mathrm{ppm})+$ Formalin $(500 \mathrm{ppm})$

Soaked for $18-24 \mathrm{~h}$ in solution ( $10 \mathrm{l}$ of water + $12.5 \mathrm{ml}$ Formaldehyde $+0.7 \mathrm{~g}$ Bavistin per $\mathrm{kg}$ substrate)

Different substrates treated with solution of Carbendazim (75ppm) + Formalin (500ppm) for $18 \mathrm{hr}$

Paddy straw, wheat straw, apple leaves and chinar leaves treated with formalin solution (36:1 ratio of water to formaldehyde) and carbendazim solution (1 gm Carbendazim in $10 l$ of water)

Wheat straw, grounded pulse powder and rice bran treated with solution $(100 l$ water $+5 \mathrm{~kg}$ limestone)

Paddy straw soaked with $1 \%, 3 \%$, and $5 \%$ (v/v) solution of $1 \mathrm{~kg}$ onion $+0.5 \mathrm{~kg}$ garlic $+10 \mathrm{l}$ water

Alkaline immersion technique $70 \mathrm{~kg}$ substrate immersed in solution ( $2 \%$ calcium hydroxide $+350 l$ water) for $12 \mathrm{~h}$

Substrate disinfected with alkaline solution for $12 \mathrm{~h}$
Resulted poor yields in Pleurotus sp. and took longer duration for the completion of mycelial growth due to unavailability of carbon sources

Complete prevention of competitor molds, with highest yield of $129.5 \mathrm{~g} / 1 \mathrm{~kg}$ substrate from formaldehyde and

bavistin treated substrate. But, up to $39.33 \%$

contamination incidence was observed; twice that of hot water treatment

Average yields of Pleurotus sp. varied between 681.72 to $742.98 \mathrm{~g} / \mathrm{kg}$ substrate and H. Ulmariusn was $855.52 \mathrm{~g} / \mathrm{kg}$ substrate

Highest yield of Pleurotus sp. (1700g/2kg with $85.9 \%$ B.E)

Average biological efficiencies of all seven Pleurotus sp. cultivated varied from $35 \%$ to $85.2 \%$

Substrate supplemented with 5\% soybean flour produced highest yield of $675 \mathrm{~g} / 2 \mathrm{~kg}$ substrate for P. sajor-caju and $670 \mathrm{~g} 2 \mathrm{~kg}$ substrate for $P$. florida

Highest yield of $747.1 \mathrm{~g} / 500 \mathrm{~g}$ dry weight with $149.4 \%$

B.E was obtained using paddy straw followed by wheat straw $(623.7 / 500 \mathrm{~g}$ with $124.7 \%$ B.E), apple leaf (478.1/500g with $95.62 \%$ B.E) and chinar leaf (426.8/500g with $85.3 \%$ B.E)

Lime stone acts as anti-bacterial agent against competitor Khan, 2004 organisms and also reduces the acidity of substrate which is not ideal for mycelium growth

Highest yield was recorded $2.5 \%$ onion-garlic solution $(113 \mathrm{~g} / \mathrm{kg})$. Protasan-DC yielded nothing, because of $100 \%$ contamination by Coprinuss pp.

Average mushroom yield was $684.7 \mathrm{~g} / 3.4 \mathrm{~kg}$ bag with B.E of $57.6 \%$

$62 \%$ of biological efficiency was obtained and study also showed the drawbacks as reported by De León-Monzón et al., 2004
Muhammad et al., 2007

Saritha and Pandey, 2010

Shukla and Jaitly, 2011; Rajak et al., 2011

Rajak et al., 2011

Chandravanshi et al., 2012 Singh and Prasad, 2012

Pala et al., 2012

Saritha and Pandey, 2010

Hernandez and Sánchez, 2013

Barrios-Espinoza et al., 2009
Hernandez et al. (2003) developed self-heating method of disinfection without using any heating source, stacking the substrate and allowing it for 2 to 3 days that build-up heat inside straw bulk. Though this method was feasible in experimental condition, but it failed to pasteurize entire volume of substrate except centre and top layers of substrate. To overcome this drawback Barrios-Espinoza et al. (2009) and Sanchez et al. (2011) modified this method by increasing the substrate mass and volume using a wooden crate $\left(1 \mathrm{~m}^{3}\right)$ containing $230 \mathrm{~kg}$ substrate at $65 \%$ moisture. Under experimental conditions this method showed positive result in pasteurising the whole mass of substrate. Barrios-Espinoza et al. (2009) achieved highest BE of $112 \%$ from self-heated substrate. Hernandez and Sánchez, (2013) conducted study on self-heating pasteurization of Pangola grass by developing similar setup as suggested by Sanchez 
Table 3: Non-chemical sterilization of various substrates used in mushroom cultivation

\begin{tabular}{|c|c|c|c|}
\hline Substrate & Pre-treatment & Inference & Reference \\
\hline Paddy straw & Autoclave at $15 \mathrm{psi}$ & $\begin{array}{l}\text { Maximizes the biological efficiency of Pleurotussajor- } \\
\text { caju }\end{array}$ & Krishnamoorthy, 1981 \\
\hline Paddy straw & $\begin{array}{l}\text { Steam sterilization at } \\
121^{\circ} \mathrm{C} \text { for } 1 \mathrm{~h}\end{array}$ & $\begin{array}{l}\text { Undue method for industrial scale with devastating } \\
\text { effect on competitor molds and pathogens }\end{array}$ & $\begin{array}{l}\text { Rajarathnum and } \\
\text { Bano, } 1987\end{array}$ \\
\hline Sunflower thrash & $\begin{array}{l}\text { Cold water immersion } \\
\text { for } 8,16,24 \text { and } 32 \mathrm{hr} \text {; } \\
\text { Hot water immersion for } \\
30 \text { minutes; Boiling in } \\
\text { water for } 30 \text { minutes; } \\
\text { Autoclaved at } 121^{\circ} \mathrm{C} \\
\text { at } 15 \text { psi pressure for } \\
30 \text { minutes }\end{array}$ & $\begin{array}{l}\text { Pleurotussajor-caju offered highest yield when } \\
\text { substrate was autoclaved for } 30 \text { minutes at } 15 \text { psi }\end{array}$ & Balakrishna et al., 2001 \\
\hline $\begin{array}{l}\text { Sugarcane bagasse and } \\
\text { horse manure compost }\end{array}$ & $\begin{array}{l}\text { Autoclaved at } 121^{\circ} \mathrm{C} \text { for } \\
4 \mathrm{~h} \text {; Hot water pasteuri- } \\
\text { sation at } 60^{\circ} \mathrm{C} \text { for } 2 \mathrm{~h} \text { and } \\
\text { Hot water pasteurisation } \\
\text { at } 60^{\circ} \mathrm{C} \text { for } 3 \mathrm{~h}\end{array}$ & $\begin{array}{l}\text { Though, autoclaved bagasse gave best yield ( } 410.4 \mathrm{~g} / 1 \mathrm{~kg} \\
\text { substrate with BE of } 82.10 \%) \text {, the hot water pasteurized } \\
\left(60^{\circ} \mathrm{C} \text { for } 3 \mathrm{~h} \text { ) bagasse proved to be a feasible method }\right. \\
\text { particularly for rural areas, owing to cost and capacity } \\
\text { considerations }\end{array}$ & Oseni et al., 2012 \\
\hline $\begin{array}{l}\text { Coir pith, maize straw, } \\
\text { paddy straw, sugarcane } \\
\text { bagasse, sugar-cane leaves } \\
\text { and vettivera leaves }\end{array}$ & $\begin{array}{l}\text { 1. Steam treatment } \\
\text { in autoclave for } 15,30 \text {, } \\
45,60,75 \text { and } 90 \text { minutes } \\
\text { 2. Substrate soaked for } \\
\text { 6h and steamed at } 121^{\circ} \mathrm{C} \\
\text { for } 60 \mathrm{~min}\end{array}$ & $\begin{array}{l}\text { Substrate soaked for } 6 \mathrm{~h} \text { and steamed at } 121^{\circ} \mathrm{C} \text { for } \\
60 \text { min produced maximum yield of Calocybe indica } \\
\text { with } 0.6 \% \text { contamination; projecting the economic } \\
\text { viability }\end{array}$ & $\begin{array}{l}\text { Lakshmipathy et al., } \\
2012\end{array}$ \\
\hline $\begin{array}{l}\text { Mixture of wheat straw } \\
(94 \%) \text {, wheat bran }(5 \%) \\
\text { and gypsum }(1 \%)\end{array}$ & $\begin{array}{l}\text { 1. Autoclave sterilization } \\
\text { at } 121^{\circ} \mathrm{C} \text { for } 1.5 \mathrm{~h} \\
2.1 \%, 3 \% \text { Formaldehyde } \\
(\mathrm{v} / \mathrm{v})\end{array}$ & $\begin{array}{l}\text { Pleurotus sp. yield was found to vary with the } \\
\text { disinfection method; highest yield was found from } \\
\text { sterilized substrate }\end{array}$ & $\begin{array}{l}\text { Kibar and Peksen, } \\
2008\end{array}$ \\
\hline
\end{tabular}

et al. (2011). Five different Pleurotus species were grown from substrate drawn from top, middle and top layers after $48 \mathrm{~h}$ of self-heating. The yields obtained were in the range of 896 to $1331 \mathrm{~g} / 3.4 \mathrm{~kg}$ bag with B.E of 75.3 to $111.9 \%$.

\section{Pasteurization of Substrate}

Substrate pasteurization can be done either by steam or hot water at a temperature range of $80^{\circ} \mathrm{C}$ for $2 \mathrm{~h}$ (Bahukhandi and Munjal 1989; Balasubramanya and Kathe, 1996). However, pasteurization of agro residues is done at wide range of time and temperature combinations. The substrate pasteurization using hot water and steam and the yields of various mushrooms obtained are shown in Table 4. Bulk pasteurization is also another common practise followed by large scale mushroom growers in order to disinfect large volume of substrate using hot water or live steam. The different methods reported by various workers were summarized in Table 5. Majority of small scale mushroom growers uses normal oil drums as boiling equipment with little or no modifications which is an inexpensive method. Though this method is inefficient and unhygienic the method has become usual from decades. These drum can be used to pasteurize both chopped straw and straw bags. Dewraj Taurachand (2004) showed substrate can also by pasteurized by filling into gunny bags or polyethylene bags, these bags are arranged in layers inside pasteurizer drum with enough space for steam circulation. Then heating water either by electricity or burning fuel until the temperature reaches $60-70^{\circ} \mathrm{C}$ and maintain it for 3-4 hours. Kwon and Kim (2004) reported another method for pasteurization of substrate in bags. Substrate bags are stacked and placed above shelves, entire shelves was covered with plastic sheet or tarpaulin to form a tent like structure. Hot steam from steam boiler is directly allowed into tent for required time and temperature of pasteurization. Ukoima et al. (2009) disinfected substrate by filling in to plastic bags and 
Table 4: Studies conducted on substrate pasteurization

\begin{tabular}{|c|c|c|}
\hline T-t combination & Inference & Reference \\
\hline $\begin{array}{l}\text { Hot water immersion at } 65 \pm 5^{\circ} \mathrm{C} \text { for } \\
10 \mathrm{~min} \text { to } 1 \mathrm{~h}\end{array}$ & $\begin{array}{l}\text { Averts the competitor organisms and provide favorable environ- } \\
\text { ment for growth of Pleurotus spp. mycelium }\end{array}$ & $\begin{array}{l}\text { Kurtzman and Zadrazil, } \\
1982\end{array}$ \\
\hline $\begin{array}{l}\text { Hot water treatment at } 55-58^{\circ} \mathrm{C} \text { for } \\
6-24 \mathrm{~h}\end{array}$ & For better growth of mushroom with less contamination & Mateescu, 1985 \\
\hline Hot water treatment at $70^{\circ} \mathrm{C}$ for $24 \mathrm{~h}$ & Beneficial to mushroom growth & Miroslava Ziombra, 1991 \\
\hline Hot water treatment at $90^{\circ} \mathrm{C}$ for $5 \mathrm{~h}$ & Optimum growth of Pleurotus in polyethylene bags & Dravininkas, 1997 \\
\hline $\begin{array}{l}\text { Hot water treatment at } 70-80^{\circ} \mathrm{C} \\
\text { for } 4-6 \mathrm{~h} \text { and six fungicides } \\
\text { (paddy straw substrate) }\end{array}$ & $\begin{array}{l}95 \% \text { B.E was recorded for hot water treatment, except mancozeb } \\
\text { at } 100 \mathrm{ppm} \text { remaining treatments gave significantly higher yields } \\
\text { that of untreated substrate }\end{array}$ & Pani and Das, 1998 \\
\hline $\begin{array}{l}\text { Hot water treatment at } 58 \text { to } 80^{\circ} \mathrm{C} \\
\text { for } 24,48,72 \text { and } 96 \mathrm{~h} \text { (wheat } \\
\& \text { rye straw) }\end{array}$ & $\begin{array}{l}\text { Highest yield of Pleurotus was obtained from straws pasteurized } \\
\text { for } 48 \text { hours }\end{array}$ & $\begin{array}{l}\text { Ziombra and Fiedorow, } \\
1998\end{array}$ \\
\hline $\begin{array}{l}\text { Cereal straw as disinfected in hot } \\
\text { water at } 60-65^{\circ} \mathrm{C} \text { for } 2 \mathrm{~h} \text { and steam at } \\
60^{\circ} \mathrm{C} \text { for } 2-3 \mathrm{~h} \text { inside room containing } \\
12 \mathrm{~h} \text { pre-soaked substrate }\end{array}$ & Better yields of mushrooms with less chances of contamination & Viziteu, 2004 \\
\hline $\begin{array}{l}\text { Corn cob substrate disinfected by } \\
\text { boiling in water for } 10 \mathrm{~min} \text {; boiling in } \\
\text { water for } 1 \mathrm{~h} \text {; substrate scalded with } \\
\text { boiled water }\left(100^{\circ} \mathrm{C}\right) \text {; substrate } \\
\text { disinfected with a fungicide solution } \\
\text { (Derosal } 0.01 \%) \text {; and substrate soaked } \\
\text { in normal water for } 24 \mathrm{~h}\end{array}$ & $\begin{array}{l}\text { Best spawning rate was obtained for substrate boiled for one } \\
\text { hour, while highest and earlier yields of Oyster mushroom } \\
\text { was obtained from substrate scalded with boiled water }\end{array}$ & Diana et al., 2006 \\
\hline $\begin{array}{l}\text { Cotton waste disinfected in boiling } \\
\text { water for } 30 \text { minutes; steam pasteuri- } \\
\text { zation at } 80^{\circ} \mathrm{C} \text { for } 1 \mathrm{~h} \text {; and chemical } \\
\text { sterilization with formalin }\end{array}$ & $\begin{array}{l}\text { The steam pasteurization produced best results for all three } \\
\text { Pleurotus species cultivated, followed by formalin, hot water } \\
\text { and control (without pasteurization) }\end{array}$ & Muhammad et al., 2007 \\
\hline $\begin{array}{l}\text { Paddy straw was pasteurized by ten } \\
\text { different methods which include } \\
\text { steaming }\left(80^{\circ} \mathrm{C} \text { for } 2 \mathrm{~h} \text { in autoclave }\right) \text {, } \\
\text { hot water }\left(80^{\circ} \mathrm{C} \text { for } 60 \mathrm{~min}\right) \text { and } \\
\text { chemical methods }\end{array}$ & $\begin{array}{l}\text { The average yield obtained from hot water treatment was } 51.35 \% \\
\text { more than that of chemical sterilization technique. Hot water } \\
\text { treatment was best method even though steam treatment } \\
\text { offered highest yield, but steam method failed to prevent the } \\
\text { contamination (Trichoderma and Coprinus spp) }\end{array}$ & Saritha and Pandey, 2010 \\
\hline $\begin{array}{l}\text { Paddy straw was pre-soaked for } 2 \mathrm{~h} \\
\text { and pasteurized in hot water } \\
\left(80^{\circ} \mathrm{C} \text { for } 60 \mathrm{~min}\right)\end{array}$ & Calocybe indica yield of $450.6 \mathrm{~g} / 1 \mathrm{~kg}$ substrate was obtained & Senthilnambi et al., 2011 \\
\hline
\end{tabular}

then placing bags inside a drum with hot water at 60 $62^{\circ} \mathrm{C}$ for $3 \mathrm{~h}$. Kurtzman (2010) developed an inexpensive method for pasteurizing substrate by using two ordinary steel drums as pasteurizing vessels. This method involved heating the water inside the drums up to $60^{\circ} \mathrm{C}$ and immersing the straw into hot water using wire basket with a holding time of 30 to $60 \mathrm{~min}$. Later wire basket containing substrate can be pulled out from drums by using chain and pulley assembly which can be handled by single operator. It is possible to pasteurize one ton of dry substrate per batch in 810 hour. Even FAO suggested similar technique, using
$200 l$ oil drum with bamboo screen at bottom of drum with 4 inches of clean water. Water is heated until steam rises up through the bags and temperature of $90-100^{\circ} \mathrm{C}$ is maintained for $3-4 \mathrm{~h}$ (Anon, 2001). All these methods are unhygienic, inefficient, difficult to handle, and high chances of re-contamination.

Gowda and Kumar (2014) have developed a hot water substrate pasteurizer having capacity of 25 $\mathrm{kg}$ dry substrate per batch. The system have facility to disinfect the substrate at a temperature between $50^{\circ} \mathrm{C}$ to $80^{\circ} \mathrm{C}$ for required time period without any risk of contamination. This setup is an inexpensive, 
Table 5: Studies conducted on bulk pasteurization of substrate with steam and hot water

\begin{tabular}{lll}
\hline T-t combination & Inference & Reference \\
\hline Steam pasteurization of substrate between & The pathogenic fungi and bacteria in substrate mixture will & Zadrazil and Schneidereit, \\
$60-100^{\circ} \mathrm{C}$ for $2-6 \mathrm{~h}$ & be killed making more favorable for mycelial running of & 1972 \\
& Pleurotus spp.
\end{tabular}

Heating substrate for $6 \mathrm{~h}$ at $60^{\circ} \mathrm{C}$

Kills green molds present in straw, while to kill flies \& nematodes mild time-temperature treatments are sufficient

Substrate pasteurized by pouring hot water into straw at $60^{\circ} \mathrm{C}$ and held for 30-60min

Few years later the conditions changed and reorganized which seems to be more favourable for oyster mushroom

Mixer method that uses a large concrete mixer to mix substrate at $60 \pm 3^{\circ} \mathrm{C}$ for 30-60 min

1. Short fermentation 2. Steam pasteurization $\left(60-70^{\circ} \mathrm{C}\right.$ for $\left.12 \mathrm{~h}\right)$ and $61.75 \%$ for steam treatment

of various agro-residues

Sugarcane substrate disinfected by soaking and heating till start of boiling; soaking and boiling for 15, 30, 45, 60, 75, $90 \mathrm{~min}$; and soaking for 24 hours and boiling for $30 \mathrm{~min}$

Bulk (20-30 kg) paddy straw pasteurizer cum excess moisture reducer, can heat water between $60-95^{\circ} \mathrm{C}$ for required time period

Paddy straw pasteurized at $60^{\circ} \mathrm{C}$ for $4 \mathrm{~h}$, $70^{\circ} \mathrm{C}$ for $3 \mathrm{~h}$ and $80^{\circ} \mathrm{C}$ for $2 \mathrm{~h}$ under three different compressed levels (without compression, $50 \%$ compressed \& maximum compressed)
The mixer conditions differ from drum method, the dry substrate was added to the hot water, which was found to be more effective way of disinfection

The B.E. of P. Ostreatus was $59.52 \%$ for short composting

The maximum percent yield $(61.75 \%)$ from substrate soaked and boiled for 75 minutes and there was no yield in case of soaking till start of boiling and soaking and boiling for 15 minutes

Substrate can be loaded, compressed, and pasteurized using this machine. Also offers flexibility in time-temperature maintenance, loading-unloading substrate, draining out excess substrate moisture, and hygienic operation

The highest yields of H. ulmariusn, P. sajor-caju and C. indica were obtained from substrate pasteurized at $80^{\circ} \mathrm{C}$ for $2 \mathrm{~h}$ under maximum compressed level during pasteurization
Overtijns, 1981

Kurtzman, 1975;

Kurtzman, 1979a;

Kurtzman, 1979b

Kurtzman, 2010

De Siqueira et al., 2012

Pathan et al., 2009

Gowda and Kumar, 2014

Gowda et al., 2014

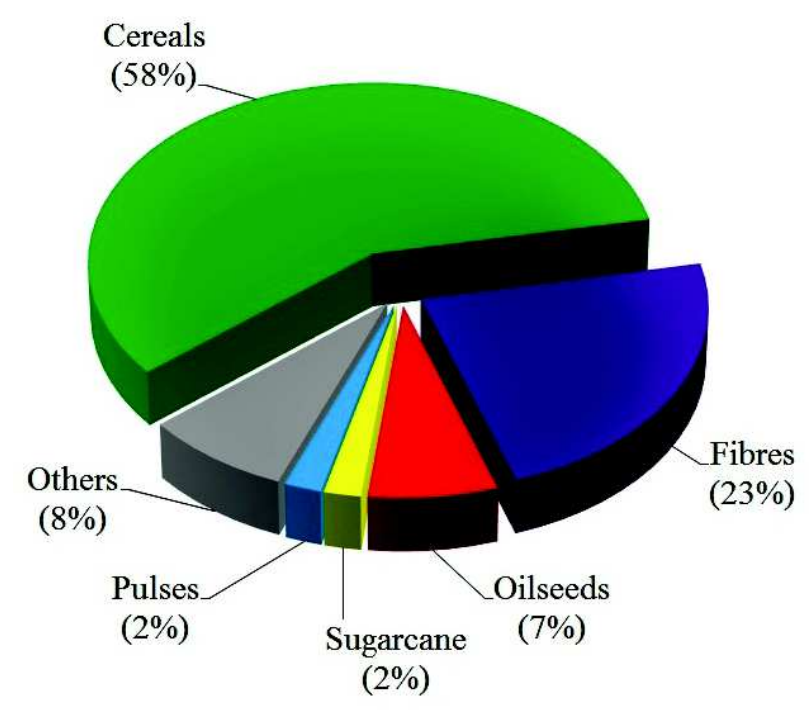

Fig. 1: Surplus crop residues available in India (MNRE, 2009)

hygienic, energy efficient, portable, and has provision for multi functions such as loading, compacting the straw, substrate heating, draining excess water, substrate cooling and unloading by a common man without drudgery. The developed setup is an ideal technology for mushroom growers, to pasteurize any agricultural residue and effectively use them for mushroom cultivation.

\section{Summary}

In this review, the most commonly used or newly developed substrate disinfection methods and their superiority in mushroom cultivation were shown. All the above reported methods for boiling, pasteurization, sterilization and fermentation of agricultural residues are not easy, high energy input, labour intensive and complicated, this motivates the growers to adopt chemical sterilization. The chemical sterilization drags most of the interest since this method eases all the complication faced in other methods. However, there are lot of drawbacks in this technique which include: use of carcinogenic chemicals effect the health of workers inhaling these fumes, create environmental 
pollution, chemical residues in mushrooms can cause chronic diseases, and also repeated use of chemicals may lead to development of resistance among competitor moulds. Most importantly, it was evident from many studies that chemical method is not effective in killing all the competitors which leads to the reduction in yield and $100 \%$ loss of crop in many farms. Yield reduction is because of non-softening of straw, which prevents efficient substrate colonization and damage the mycelium growth. This is due to the partial breakdown of the lignin-cellulose bonds, favouring substrate contamination. Another benefit of pasteurized substrate over chemical sterilization is that the generated waste after mushroom cultivation will be organically rich in nutrients such as nitrogen, phosphorus, potash, iron, zinc, manganese and copper as high as farm yard manure, which can be utilized as fertilizer for growing cash crops by farmers. This creates solutions for both agro residues utilization and eco-friendly disposal of those wastes generated from mushroom cultivation.

During pasteurization, the substrate temperature will remain around $60^{\circ} \mathrm{C}$ which needs almost $16 \mathrm{~h}$ for cooling to $25^{\circ} \mathrm{C}$ before spawning. Cooling period is the time where most of beneficial organisms will grow. Thus if straw is sterilized at $121^{\circ} \mathrm{C}$, it takes even more time for cooling which arises the contamination problems in sterilized substrate as reported by many studies. The maintenance of large quantity of sterilized substrate free of contaminant growth until spawning is arduous. And also sterilization kills beneficial organisms which will compete against contaminant growth when those organisms are killed, thus sterilized substrate becomes free for contaminants growth. An example of beneficial organisms is nitrogen fixing bacteria which plays crucial role in $\mathrm{C}: \mathrm{N}$ ratio of substrate. The growth of contaminants consumes hemicellulose during their growth hence growth of mushroom will be restricted. Thus, the purpose of pasteurization is to get rid of those that compete with mushroom not to kill everything unlike sterilization. In

\section{References}

Abe E, Eira A F and Minhoni M T A (1992) Relacoes entre temperatura de pasteurizacao e contaminacao do compostodurante o cultivo de Pleurotusostreatus (Jacquim Fries) Kummer Cientifica 20 423-433 addition any commercial mushroom grower needs to disinfect many tons of substrate every day which will consume a large amount of time, labour intensive, energy input, and the cost of equipments makes it expensive and unaffordable for mushroom growers.

Hence, it is advised to pasteurize the substrate either by steam or hot water which is more appropriate for small scale mushroom growers, as these substrates are more stable and less susceptible to contamination. The results of growth and yield of mushrooms obtained among various researchers remains contradictory most of time. Even though the experiments are conducted under similar conditions, results will vary widely depending upon several factors such as quality of spawn, effectiveness of pasteurization, quality substrate, substrate moisture, nutrients availability, unhygienic condition, cross contamination, environmental factors during growth period like light intensity, temperature, aeration, and relative humidity.

\section{Research Needs}

Despite the development of several methods for substrate disinfection, pasteurization is found to be the most efficient disinfection method. There is scope for developing low cost energy efficient pasteurization methods by using solar energy to produce hot water and steam which would be ideal to tackle energy crisis. Though there are few trials been conducted to disinfect the substrate by ionising radiation, still there are no considerable results been reported. So disinfection of soaked substrate by radiation can be studied and optimised. There are limited reports on pasteurization of substrate using microwave energy. Since the microwave is capable of heating any quantity of substance rapidly and uniformly, microwave energy can be exploited for rapid and uniform disinfection of large quantity of substrate after soaking. The development of low cost appropriate pasteurization equipments is the need of hour for mushroom growers to solve the most critical problems encountered in mushroom cultivation.

Anon (2001) FAO Mushroom cultivation for people with disabilities: a training manual. RAP Publication http:// www.fao.org/docrep/004/ab497e/ab497e00.htm. Accessed on $31 / 07 / 2013$

Anon (2013) NAAS Management of Crop Residues in the Context of Conservation Agriculture Policy Paper No. 58, National 
Academy of Agricultural Sciences, New Delhip.12ApahideanAl S (2006) Ciuperci cultivate si din flora spontana, Ed. pp142, AcademicPres Cluj-Napoca

Bahukhandi D and Munjal R L (1989) Cultivation of Pleurotus species on different agricultural residues Indian Phytopathology 42 492-495

Balakrishna J N and Earanna K S Shetty (2001) Sunflower plant waste can be a new substrate for oyster mushroom production Mysore Journal of Agricultural Sciences $\mathbf{3 5}$ 203-205

Balasubramanya R H and Kathe AA (1996) An inexpensive pretreatment of cellulosic materials for growing edible oyster mushrooms Biol Resour Technol 57 303-305

Barrios-Espinoza B M, Moreno-Ruiz L and Sanchez JE (2009) Composting in wooden boxes as substrate pre-treatment for cultivating Pleurotusostreatus Rev Mex Mic 29 51-59

Bisaria R, Madan M and Vasudevan P (1997) Utilization of agroresidues as animal feed through bioconversion Bioresource Technology 59 5-8

Chandravanshi M K, Sairkar P K, Sharma V, Chouhan S, Shukla N P and Gautam S P (2012) A comparative study of mycoprotein conversion potency of seven different species of Pleurotus from various agro-wastes International Journal of Agri Science 2 149-160

Chang S T (2008) Overview of mushroom cultivation and utilization as functional foods. Mushrooms as functional foods 260

Chang S T and Hayes W A (2013) The biology and cultivation of edible mushroom Academic Press New York USA

Chang ST, Lau OW, and Cho KY (1981) The cultivation and nutritional value of Pleurotussa jorcaju Europ J Appl Microbiol 12 58-62

Choi K W (2004) Cultivation modes: Shelf cultivation of oyster mushroom

Kwon H and B Sik Kim Mushroom Grower's Handbook-1. Korea p. 153-165 Mushworld

Christensen and Clyde Martin (1969) Common edible mushrooms. University of Minnesota Press 20

Contreras E P, Sokolov M, Mejía G and Sánchez J E (2004) Soaking of substrate in alkaline water as a pre-treatment for the cultivation of Pleurotusostreatus The Journal of Horticultural Science and Biotechnology 79 234-240

De Leon-Monzon J H, Sánchez J E and Nahed-Toral J (2004) Pleurotusostreatus cultivation in Los Altos de Chiapas México Rev Mex Mic 18 31-38

De Siqueira1 Félix, William G, Maciel Emerson P, Martos T, Gilvan C, Duarte Robert NG, Miller Romildo da Silva and
Eustáquio S Dias (2012) Cultivation of Pleurotus mushrooms in substrates obtained by short composting and steam pasteurization African Journal of Biotechnology 11 11630-11635

Denham TG (1975) The 3-phase-1 system. In: Hayes WA, ed. Composting p 67-77 The Mushroom Grower's Assn London

Devi S, Gupta C, Jat S L and Parmar M S (2017) Crop residue recycling for economic and environmental sustainability: The case of India Open Agriculture 2 486-494

Dewraj Taurach and (2004) Substrate: Sugarcane bagasse. Mushroom Grower's Handbook-1 Korea Pp 112-115 Mushroom world

Diana F, Indrea D, Apahidean A S, Apahidean M R, Pop Moldovan Z, MãniuÑiu D, Ganea R and Paven I (2006) Importance of substrate dizinfection on Oyster mushroom (Pleurotus sp.) culture Not Bot Hort Agrobot Cluj 34 1-6

Dravininkas A (1997) Investigation of the technological parameters of Pleurotus cultivation Zemes UkioInzinerija Mokslo Darbai 29 73-86

Falck R (1917) Uber die walkulter des Austernpilzes (Agaricusostreatus) auf laubholzstubben z Forst Jogdwes 49 159-165

Gowda NA N and Kumaran G S (2014) Design and development of hot water paddy straw pasteurizer for mushroom cultivation Agricultural Mechanization in Asia Africa and Latin America 45 11-18

Gowda N A N, Kumaran G S and M Pandey (2014) Performance evaluation of paddy straw pasteurizer for mushroom cultivation Agricultural Mechanization in Asia Africa and Latin America 45 28-36

Hernandez D, Sanchez J E and Yamasaki K (2003) A simple procedure for preparing substrate for Pleurotusostreatus cultivation Bioresour Technol 90 145-150

Hernandez R J A and Sánchez J E (2013) Self-pasteurised substrate for growing oyster mushrooms (Pleurotus spp) African Journal of Microbiology 7 220-226

Hiloidhari M, Das D and Baruah D C (2014) Bioenergy potential from crop residue biomass in India Renewable and sustainable energy reviews 32 504-512

Indrea D and Apahidean Al S (1995) Ghid practice pentruculturalegumelor, Ed. Ceres, Bucuresti

Khan Ahklaq (2004) Substrate-Non sterilized wheat straw Kwon, H. and B. Sik Kim. Mushroom Grower's Handbook-1. Korea. Pp 123-128 Mushworld

Kibar B and Peksen A(2008) Modelling the effects of temperature and light intensity on the development and yield of 
different Pleurotus species Agric Tropica Subtropica 41 68-73

Kligman A M (1950) A Basidiomycete probably causing onychomycosis Journal of Investigative Dermatology 14 $69-70$

Krishnamoorthy K V (1981) Microbial and chemical studies on the cultivation of Pleurotussajor-caju (Fr) singer (Oyster mushroom) M.Sc Thesis University of Agricultural Sciences Bangalore p1-98

Kurtzman R H J and Zadrazil F (1982) Physiological and taxonomical consideration for cultivation of oyster mushroom, in tropical mushroom's biological nature and cultivation methods Eds 299

Kurtzman R H Jr. (1975) Mushrooms as a source of food protein. In: M Friedman Ed. Protein nutritional quality of foods and feeds, Part 2. 305-318 Marcel Dekker New York

Kurtzman R H Jr. (1979a) Metabolism and culture of Pleurotus the oyster mushroom. Taiwan Mushrooms 3 1-13

Kurtzman R H Jr. (1979b) Nitrogen fixation by Pleurotus Mushroom Sci 10 427-435

Kurtzman R H Jr. (2010) Pasteurization of mushroom substrate and other solids: A Review African Journal of Environmental Science and Technology 4 936-941

Kwon H and Kim BS (2004) Mushroom Grower's HandbookIOyster mushroom cultivation Korea pp 263 Mushworld

Laborde J and Delmas J (1974) Unnouveau champignon comestible cultivé Le Pleurote 1 631-652

Lakshmipathy G, Jayakumar A, Abhilash M and Raj P (2012) Optimization of growth parameters for increased yield of the edible mushroom Calocybeindica African Journal of Biotechnology 11 7701-7710

Lamptey J, Robinson C W and Moo-Young M (1985) Enhanced enzymatic hydrolysis of lignocellulosic biomass pretreated by low pressure steam auto hydrolysis Biotechnol Lett 7 531-536

Lopez A, Huerta Palacios G and Sánchez J E (1996) Contamination encountered during various phases of cultivation of Pleurotusostreatus in Tropical Mexico. In: Royse D (ed.), Proceed II Int Conf on Mush Biol Mush Prod 495-502. The Pennsylvania State University

M N R E (2009) Ministry of New and Renewable Energy Resources Govt. of India New Delhi www.mnre.gov.in/ biomassrsources

Mansur M, Klibansky M, Gutiérrez I and Gonzáles L (1992) Evaluacion de parametros de processopara la produción de hongosdelgênero Pleurotus cultivadossobrepaja de cana Boletim GEPLACEA 9 11-21
Mateescu N (1985) Culturabure Ñilor, Ed. Ceres, Bucuresti

Miroslawa Ziombra (1991) Influence of Substrate Pasteurisation methods on the yielding of some Pleurotus cultivars Research Institute of Vegetable Crops 51 35-40

MNRE (2009) Ministry of New and Renewable Energy Resources Govt. of India New Delhi www.mnre.gov.in/ biomassrsources

Morris E, Harrington O, Doyle O R E, Clancy K J C and Griensven L V (2000) Green mould disease-The study of survival and dispersal characteristics of the weed mould Trichoderma in the Irish mushroom industry Mushroom Science 15 645-652

Mosier N, Wyman C, Dale B and Blander R (2005) Features of promising technologies for pre-treatment of lignocellulosic biomass Bioresour Technol 96 673-686

Muhammad A A, Mehmood M I, Nawaz R, Hanif M A and Wasim R (2007) Influence of substrate pasteurization methods on the yield of oyster mushroom (Pleurotus species) Pak J Agric Sci 44 300-303

Narain R, Sahu R K, Kumar S, Garg S K, Singh C S and Kanaujia R S (2008) Influence of different nitrogen rich supplements during cultivation of Pleurotus florida on maize cobs substrate Environmentalist 29 1-7

Nigam P S and Ashok P (2009) Biotechnology for agro-industrial residues utilisation: utilisation of agro-residues Springer

Oei P (1996) Mushroom cultivation Leiden The Netherlands

Oseni T O, Dlamini S O, Earnshaw D M and Masarirambi M T (2012) Effect of substrate pre-treatment methods on oyster mushroom (Pleurotusostreatus) production Int J Agric Biol 14 251-255

Overtijns A(1981) The conventional Phase II in trays and shelves Mush J 584 15-21

Pala S A, Wani A H and Mir R A (2012) Yield performance of Pleurotussajor-caju on different agro-based wastes Annals of Biological Research 3 193-194

Pani B K and Das S R (1998) Effect of pre-treatment of substrate on the yield of oyster mushroom Pleurotussajor-caju (Fr. Singer) Journal of Mycopathological Research 36 113-114

Pani B K and Das S R (1998) Seasonal productivity of summer white mushroom (Calocybeindica P.\& C.) in Orissa Science and Culture 64 177-178

Pani B, Panda S and Das S (1997) Utilization of some by-products and other wastes for sporophore production of oyster mushroom Orissa Journal Horticulture 25 36-39

Pathak H, Bhatia A, Jain N and Aggarwal P K (2010) Greenhouse gas emission and mitigation in Indian agriculture- A review, In ING Bulletins on Regional Assessment of Reactive 
Nitrogen, Bulletin No.19 (Ed. Bijay-Singh) p34 SCONING New Delhi

Pathan A A, Pathan M A, Wagan K H and Nizamani Z A (2009) Effect of soaking and boiling of substrate on the growth and productivity of oyster mushroom Pakistan $J$ Phytopathol

Philippoussis A, Diamantopoulou P and Zervakis G (2003) Correlation of the properties of several lignocellulosic substrates to the crop performance of the shiitake mushroom Lentinulaedodes World J Microbiol Biotechnol 19 551557

Quimio T H (1981) Physiological Studies on Pleurotus spp. P 299-348 Chinese University Press Hong Kong

Quimio T H, Chang S T and Royse D J (1990) Technical Guidelines for Mushroom Growing in the Tropics FAO Plant Production and Protection paper No 106. Rome Italy pp 154

Rajak S, Mahapatra S C and Basu M (2011) Yield fruit body diameter and cropping duration of oyster mushroom (Pleurotussajorcaju) grown on different grasses and paddy straw as substrates European Journal of Medicinal Plants 1 10-17

Rajarathnum S and Bano Z (1987) Pleurotus mushrooms: morphology life cycle taxonomy breeding and cultivation 26 157-223

Sanchez C (2010) Cultivation of Pleurotusostreatus and other edible mushrooms Appl Microbiol Biotechnol 85 13211337

Sánchez J E, Moreno L and Andrade-Gallegos R (2011) Pasteurization of substrate for growing Pleurotusostreatus by self heating. In: Savoie J M, Foulogne-Oriol M, Largeteau M and Barroso G (eds.) Proceed 7th Int Conf Mush Biol Mush Prod Institut Nationale de la Recherche Agronomique - World Society for Mushroom Biology and Mushroom Products Arcachon France 1 403-410

Sangwan M S and Saini L C (1995) Cultivation of Pleurotussajorcaju (Fr.) Singer on agro-industrial wastes Mushroom Research 4 33-34

Saritha B and Pandey M (2010) Evaluation of Alternate Substrate Pasteurization Techniques for Culinary-Medicinal White Oyster Mushroom, $<\mathrm{i}>$ Pleurotusostreatus $</ \mathrm{i}>$ var. $<\mathrm{i}>$ florida $</ \mathrm{i}>$ (Agaricomycetideae) Cultivation. International Journal of Medicinal Mushrooms 12

Satyendra T, Singh R N and Shaishav S (2013) Emissions from crop/biomass residue burning risk to atmospheric quality International Research Journal of Earth Sciences 1 1-5

Senthilnambi D, Eswaran A and Balabaskar P (2011) Cultivation of Calocybe indica (P and $\mathrm{C}$ ) during different months and influence of temperature and relative humidity on the yield of summer mushroom African Journal of Agricultural Research 6 771-773

Sharma S R, Satish Kumar and Sharma V P (2007) Diseases and competitor moulds of mushrooms and their managementTechnical Bulletin pp 81, National Research Centre for Mushroom (ICAR)

Shukla S and Jaitly A K (2011) Morphological and biochemical characterization of different oyster mushroom (Pleurotus spp.) Journal of Phytology 3 18-20

Sinden J W and Hauser E (1953) The nature of the composting process and its relation to short composting Mushroom Sci 2 123-130

Singh R P, Garcha H S and Khanna P K (1989) Biodegradation of Lignocellulosic in solid state fermentation (SSF) by Pleurotus spp Indian Journal of Microbiology 29 49-52

Singh S D and Prasad G (2012) Effect of different Substrate supplements on the growth and yield of two species of Mushroom P. florida and P. sajor-caju International Multidisciplinary Research Journal 2 61-64

Sokhansanj S, Mani S, Bi X, Zaini P and Tabil L G (2005) Binderlesspelletization of biomass ASAE Annual International Meeting Tampa Convention Centre Tampa FL July 17-20, pp 056061, 2950 Niles Road, St. Joseph, MI 49085-9659 USA

Stamets P (1993) Cultivation of Morels mushroom $J$ Wild Mushrooming 11 9-15

Thakur T C (2003) Crop residue as animal feed. Addressing Resource Conservation Issue in Rice-Wheat Systems of South Asia, A review book. Rice wheat consortium for Indo-Gangentic Plains (CIMMYT)

Thomsen M H (2005) Complex media from processing of agricultural crops for microbial fermentation Appl Microbiol Biotechnol 68 598-606

Treschow C (1944) Nutrition of cultivated mushroom Dansk Botanisk Arkiv 11 9-180

Ukoima H N, Ogbonnaya L O, Arikpo G E and Ikpe F N (2009) Cultivation of mushroom (Volvariellavolvacea) on various farm wastes in Obubra local government of Cross River state, Nigeria Pak J Nutr 8 1059-1061

Valencia N R and Lopez C J (2005) Cultivo de hongos comestibles delgénero Pleurotus sobreresiduosagrícolas de la zonacafetera. Centro Nacional de Investigaciones de café "Pedro Uribe Mejía" Cenicafé. Chinchina-CaldasColombia Boletín Técnico 27

Vijay B and Sharma S R (1996) Effect of chemical treatment of 
long method compost on yellow moulds, compost microflora and yield of Agaricusbisporus pp 503-514 Mushroom Biology and Mushroom Products (DJ Royse, ed.)

Villaceran A B, Kalaw S P, Nitural P S, Abella E A and Reyes R G (2006) Cultivation of Thai and Japanese strains of Pleurotussajor-caju on rice straw - based Volvariella volvacea mushroom spent and composted rice straw in Central Luzon Region, Philippines Journal of Agricultural Technology 2 69-75

Wood D A and Smith J F (1987) The cultivation of mushrooms. In: Norris J R and Pettipher G L (eds) Essays in Agricultural and Food Microbiology John Willey and Sons Ltd London
Zadrazil F (1975a) Die Zersetzeng des stroch - Zellulose - liguin - Komplexesmit Pleurotusflorida and dessn Netzung. Z. Pflan Zenernahs Bodenkd 138 263-278

Zanetti A L and Ranal M A (1996) Efeitos de diferentesresíduos agro industriaisnamiceliação de Pleurotus sp. "Florida", em Uber lândia, M.G. Pesquisa Agropecuária Brasileira 31 215-220

Ziombra M and Fiedorw Z (1998) Influence of substrate and pasteurization on Pleurotuseryngii yield. Ekologiczneaspektlyprodukejiagrodniczej, Poznan, Poland, 17-18 listopada, Poznaniumogrodnictwo 27373 376. 